\title{
Разработка и оценка качества сухого концентрата напитка на основе модифицированного пектина с добавлением женьшеня и элеутерококка
}

\author{
Андрей Подкорытов ${ }^{1 *}$, Ирина Кадникова ${ }^{1}$, Елена Подкорытова $^{1,2}$, \\ Валерий Ковалев ${ }^{2}$ \\ ${ }^{1}$ Дальневосточный федеральный университет, г. Владивосток, Россия \\ ${ }^{2}$ Национальный научный центр морской биологии им. А.В. Жирмунского ДВО РАН, \\ г. Владивосток, Россия
}

\section{Информация о статье \\ Поступила в редакиию: \\ 23.01.2020 \\ Принята \\ к опубликованию: \\ 20.05.2020}

УДК 663.86.054.1

JEL O14

\section{Ключевые слова:}

пектин, филлоспадикс, адаптогены, женьшень, элеутерококк, аскорбиновая кислота, функциональный продукт, безалкогольный напиток, сухой концентрат, технология

\begin{abstract}
Аннотация
Разработана технология и рецептура сухого концентрата напитка, содержащзего функииональные ингредиенты: модифицированный пектин из Phyllospadix iwatensis, гинсенозиды, элеутерозиды и аскорбиновую кислоту. Определены дозы всех ингредиентов с учетом норм суточного потребления. Исследован процесс гранулирования композиции пектина и сахарозы с добавлением настойки женьшеня и экстракта элеутерококка. Содержание пектина, гинсенозидов, элеутерозидов и аскорбиновой кислоть в однократной дозировке напитка (10 г) составляет 100\% от адекватного суточного уровня потребления каждого из данных ингредиентов. Проведена органолептическая оченка напитка и определены его основные физико-химические показатели.
\end{abstract}

Development and Quality Assessment of a Beverage Dry Concentrate Based on the Modified Pectin Added with Ginseng and Eleutherococcus

Andrey Podkorytov, Irina Kadnikova, Elena Podkorytova, Valeriy Kovalev

\begin{abstract}
The technology for producing dry concentrate for a functional beverage based on the modified pectin from the sea grass Phyllospadix iwatensis added with ginseng tincture and eleutherococcus extract is described in the article. To classify the beverage as a functional one, we used a composition containing $20 \%$ pectin. The quantitative content of the total ginsenosides (in terms of ginsenoside Rg1) was defined by the spectrophotometric method at a wavelength of $526 \mathrm{~nm}$. The eleutheroside $B$ and ascorbic acid quantity was defined by HPLC with
\end{abstract}


spectrophotometric detection at $270 \mathrm{~nm}$ and $243 \mathrm{~nm}$, respectively. To improve the organoleptic characteristics, citric acid and stevioside were added to the beverage. The beverage formula was developed in accordance with the requirements of the State Standard of Russia number 28188-2014 and with the norms of the daily consumption. The content of pectin, ginsenosides, eleutherosides and ascorbic acid in a unit dosage of the drink $(10 \mathrm{~g})$ is $100 \%$ of the adequate daily intake of each of these ingredients. The organoleptic evaluation of the drink was carried out in accordance with ISO 11035: 1994 and the State Standard of Russia number 6687.5-86. The basic physical-chemical indicators (titrated acidity, humidity, mass fraction of dry substances and minerals) were determined.

\section{Введение}

Особая роль в практике здорового питания отводится напиткам. Это связано с возможностью обогащения организма биологически активными веществами различного функционального назначения.

В последнее время в состав различных функциональных продуктов питания все чаще включают природные полисахариды, которые, с одной стороны, выполняют функцию структурирующих агентов, а с другой, - повышают биологическую ценность продукта. В этом плане большой интерес представляют пектины, структурной основой которых является D-галактуроновая кислота. Часть ее остатков в молекулах пектинов этерифицирована метиловым спиртом - метоксилирована. Степень метоксилирования пектинов является важным показателем, так как от нее зависят многие функциональные свойства пектинов. Способностью связывать и выводить из организма тяжелые металлы и радионуклиды обладают только низкометоксилированные пектины, в которых большинство остатков D-галактуроновой кислоты имеет свободные карбоксильные группы. В то же время практически все коммерческие пектины являются высокометоксилированными и не способны к образованию достаточно прочных комплексов с ионами металлов. Одним из источников низкометоксилированного пектина может служить морская трава Phyllospadix iwatensis. Пектины из морских трав обладают уникальными свойствами и широким спектром фармакологического действия [1-5]. Высокая сорбционная способность пектина из филлоспадикса позволяет рекомендовать его к использованию в качестве энтеросорбента в пищевой и фармацевтической промышленности [6-8].

В производстве функциональных безалкогольных напитков все большую популярность приобретают экстракты и настойки из отечественного лекарственного растительного сырья, которые обладают направленным биологическим действием [9]. Растительные экстракты обладают тонизирующим и антиоксидантным действием, повышают адаптивные возможности организма к воздействию неблагоприятных факторов окружающей среды, являются оптимальными источниками хорошо усваиваемых микроэлементов $[10,11]$.

В качестве источников адаптогенов, обладающих тонизирующим действием, были выбраны женьшень обыкновенный (Panax ginseng) и элеутерококк колючий (Eleutherococcus senticosus).

Целью данной работы является разработка технологии сухого концентрата напитка на основе модифицированного пектина из Phyllospadix iwatensis с добавлением женьшеня обыкновенного и элеутерококка колючего. 


\section{Материалы и методы исследования}

В работе был использован модифицированный пектин из морской травы Phyllospadix iwatensis со следующими характеристиками: степень деме-

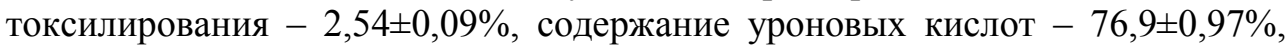
среднечисленная молекулярная масса - 52,1 кДа, средневесовая молекулярная масса - 112,21 кДа.

В качестве объектов исследований использовали настойку женьшеня обыкновенного (ОАО «Ивановская фармацевтическая фабрика», Россия) рег. № ЛП-000445, экстракт корневищ и корней элеутерококка колючего жидкий (ОАО «Дальхимфарм», Россия) по ВФС 42-1281, сахар белый по ГОСТ 33222-2015, кислота аскорбиновая по ФС 42-2668, кислота лимонная по ГОСТ 908-2004, подсластитель «стевиозид» (ООО «Витачай», Россия).

Количественное содержание суммы гинсенозидов (в пересчете на гинсенозид $\operatorname{Rg}_{1}$ ) в настойке женьшеня определяли на спектрофотометре Shimadzu UV-1800 при длине волны 526 [12]. Использовали стандарт гинсенозида $\operatorname{Rg}_{1}$ (ChromaDex, CШA).

Количественное определение элеутерозида В и аскорбиновой кислоты проводилось методом высокоэффективной жидкостной хроматографии (ВЭЖХ) с детектированием при длине волны 266 нм и 243 нм соответственно [13]. Данные по хроматографии были обработаны с помощью программы Shimadzu LabSolutions.

Органолептические показатели напитка оценивали с помощью профильного метода по ISO 11035:1994, ГОСТ 6687.5-86. Массовую долю сухих веществ в концентрате определяли по ГОСТ 6687.2-90, минеральные вещества - по ГОСТ 15113.8-77, влажность концентрата — по ГОСТ Р 52610-2006, титруемую кислотность — потенциометрически по ГОСТ 6687.4-86.

\section{Результаты исследования и их обсуждение}

На основании данных по растворимости пектина, полученных ранее [13], для разработки рецептуры напитка за основу была выбрана композиция, содержащая 20\% модифицированного пектина из филлоспадикса и $80 \%$ сахарозы.

При составлении рецептуры сухого концентрата напитка, как функционального продукта, в первую очередь рассчитывали количество функциональных ингредиентов - пектина, гинсенозидов, элеутерозидов и аскорбиновой кислоты с учетом норм их суточного уровня потребления [14].

Адекватный уровень потребления пектина составляет 2,0 г/сут. С учетом 20\% содержания пектина в смеси рассчитанная однократная (суточная) дозировка готового продукта (включая все ингредиенты) составляет 10,0 г.

Для расчета необходимого количества жидкого экстракта элеутерококка в нем было определено содержание элеутерозида В (рис. 1).

Содержание элеутерозида В в экстракте элеутерококка жидком составило 1,78 мг/мл. Соответственно, 1,0 мг элеутерозида В (суточный адекватный уровень потребления) содержится в 0,562 мл жидкого экстракта.

Для расчета необходимого количества настойки женьшеня в ней в ней было определено содержание суммы гинсенозидов. Содержание суммы гинсенозидов в настойке женьшеня составило 5,7 мг/мл. Соответственно, 5,0 мг 
гинсенозидов (суточный адекватный уровень потребления) содержится в 0,877 мл настойки.

Для достижения адекватного уровня потребления аскорбиновой кислоты ее добавляли в количестве 100 мг/10,0 г продукта (1,0\% от общей массы сухого концентрата напитка) (рис. 2).
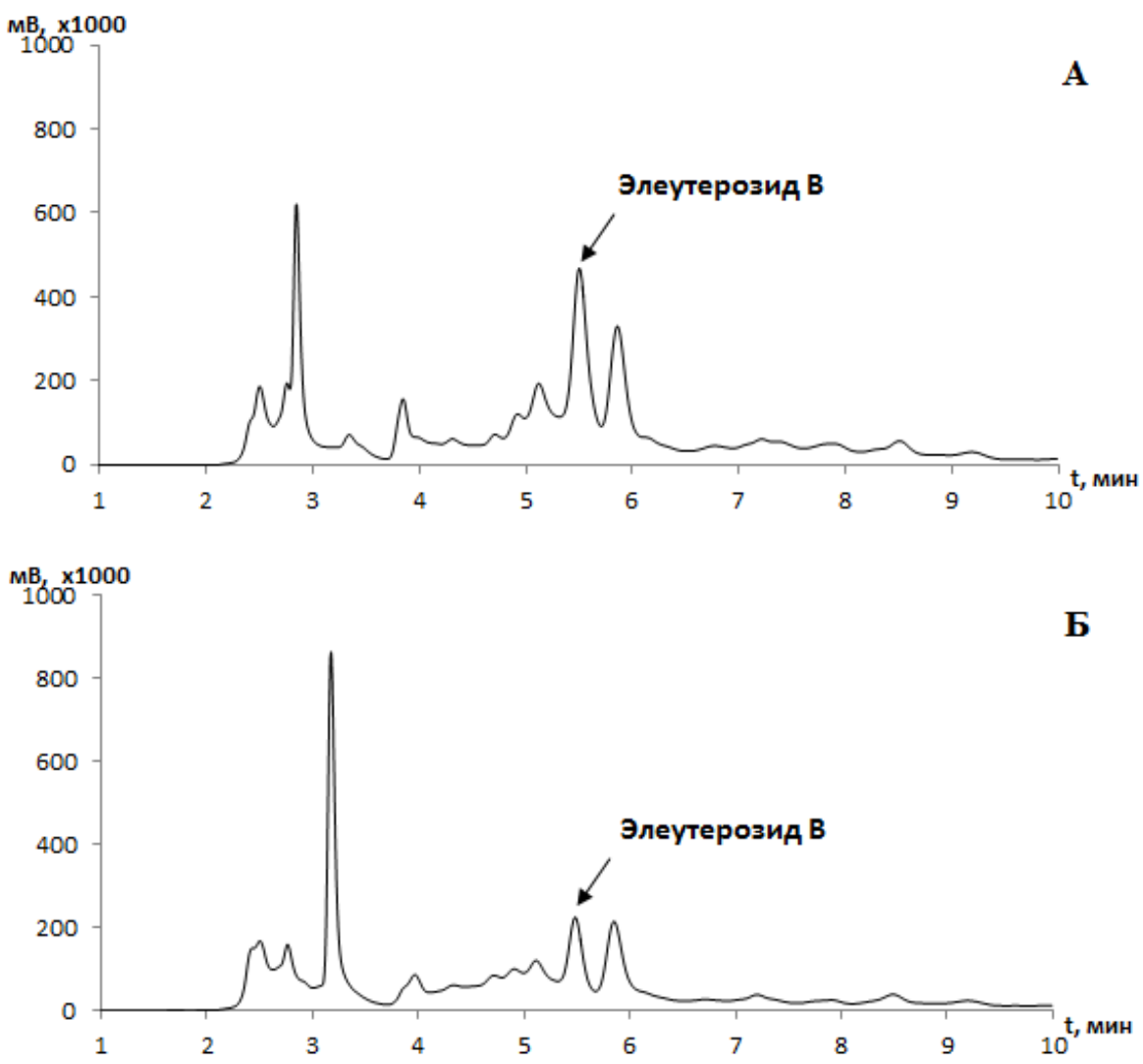

Puc. 1. Хроматограмма экстракта элеутерококка жидкого - А и готового напитка на основе пектина с добавлением женьшеня и элеутерококка - Б Источник: составлено авторами

Добавление в рецептуру лимонной кислоты и стевиозида основывалось на органолептической оценке напитка, главным образом, его вкуса.

Основываясь на результатах проведенных органолептических исследований, были установлены следующие значения содержания ингредиентов в расчете на 10,0 г сухого концентрата напитка: лимонная кислота - 40,0 мг; стевиозид $-60,0$ мг. 


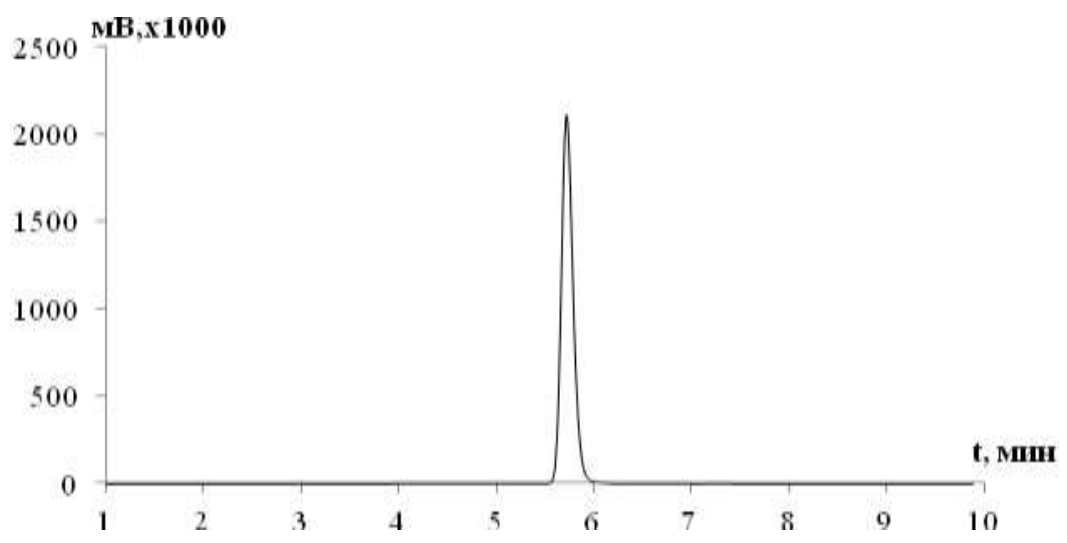

Puc. 2. Хроматограмма готового напитка - определение содержания аскорбиновой кислоты

Источник: составлено авторами

Рецептура сухого концентрата напитка представлена в табл. 1.

Таблищуа 1

Рецептура композиции сухого концентрата напитка (в расчете на 1 кг готового продукта)

\begin{tabular}{|l|c|c|}
\hline \multicolumn{1}{|c|}{ Наименование сырья } & Единица измерения & Количество \\
\hline Сахароза & г & 774 \\
\hline Модифицированный пектин из филлоспадикса & г & 200 \\
\hline Настойка женьшеня & мл & 87,7 \\
\hline Экстракт элеутерококка жидкий & мл & 56,2 \\
\hline Кислота аскорбиновая & г & 10 \\
\hline Стевиозид & г & 6 \\
\hline Кислота лимонная & г & 4 \\
\hline
\end{tabular}

Источник: составлено авторами

Производства сухого концентрата напитка осуществлялось согласно технологической схеме, представленной на рис. 3.

Сухие компоненты просеивали через сито с диаметром отверстий 0,5 мм. Затем компоненты отвешивали на весах с погрешностью не более 0,1\% в количествах, указанных в табл. 1.

Настойку женьшеня и экстракт элеутерококка отмеряли с помощью мерного цилиндра в количествах, указанных в рецептуре (табл. 1), после чего смешивали.

В сухую емкость объемом 10 л добавляли сахарную пудру, стевиозид, аскорбиновую и лимонную кислоты, затем вносили смесь жидких компонентов и вымешивали до однородной массы (визуальный контроль). При постоянном перемешивании к полученной смеси постепенно добавляли модифицированный пектин из филлоспадикса и продолжали вымешивать до получения однородной массы.

Полученную влажную массу пропускали через гранулятор с отверстиями диаметром 3-4 мм. 


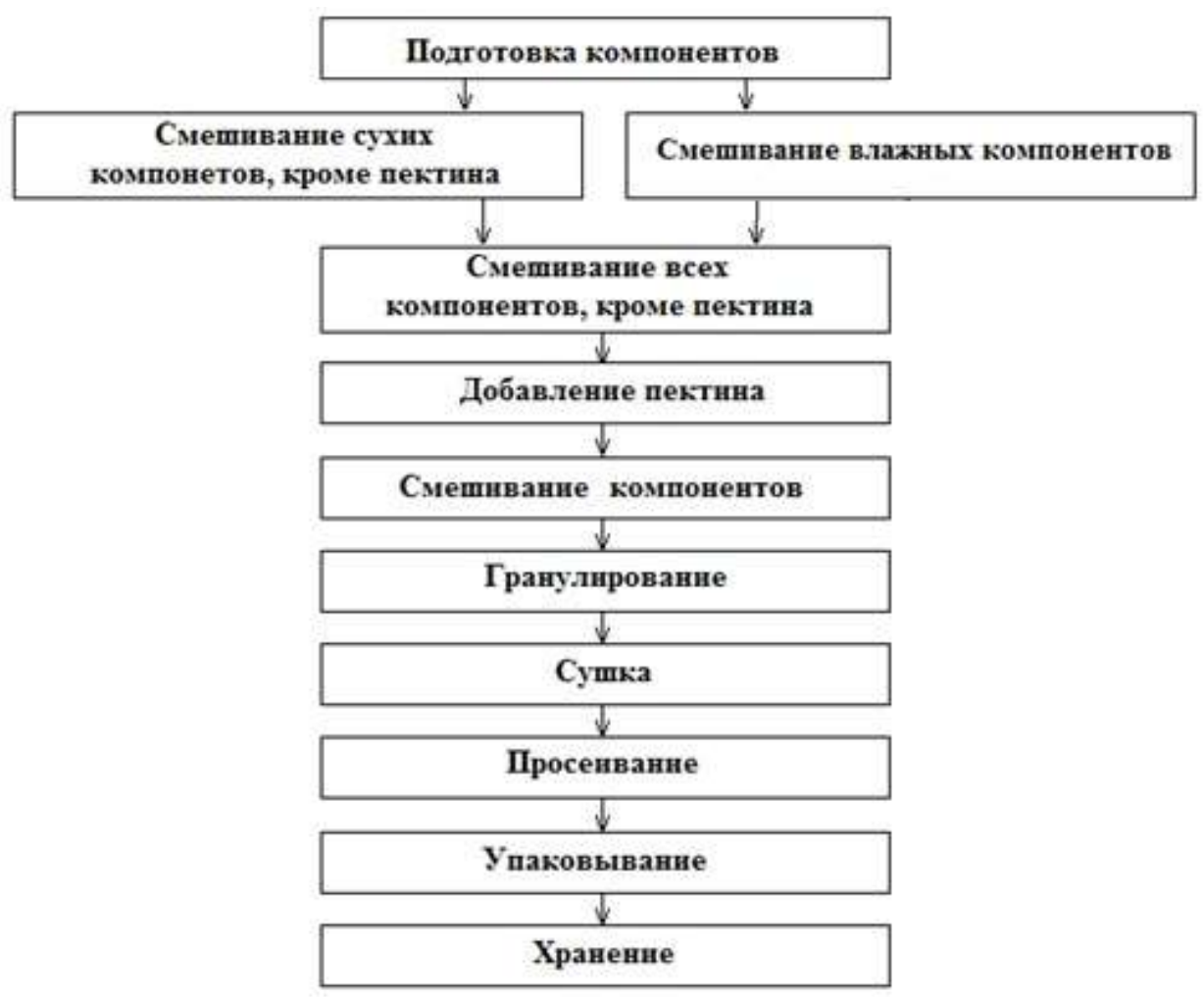

Puc. 3. Технологическая схема производства сухого концентрата напитка с добавлением женьшеня и элеутерококка

Источник: составлено авторами

Сушку гранулята осуществляли в сушилке при температуре не выше $80^{\circ} \mathrm{C}$ до остаточной влажности не более $8 \%$.

Сухой гранулят просеивали через сито с диаметром отверстий 2-3 мм. Готовый продукт проверяли на содержание гинсенозидов, элеутерозидов и аскорбиновой кислоты (рис. 1Б и 2), после чего упаковывали в герметичную тару.

С момента окончания технологического процесса сухой концентрат напитка упаковывают в потребительскую тару согласно ТР ТС 005/2011 и хранят при комнатной температуре в сухом темном месте.

Для оценки органолептических показателей напитка на основе пектина с добавлением настойки женьшеня и экстракта элеутерококка использовали профильный метод по ГОСТ 6687.5-86, ISO 11035:1994. Изучали внешний вид, цвет, вкус, запах. Для этого суточную дозу сухого концентрата напитка $(10,0$ г) растворяли в 200,0 мл воды при комнатной температуре. Данные органолептических исследований функционального напитка представлены в табл. 2 и на рис. 4. 
Органолептическая оценка приготовленного напитка на основе модифицированного пектина с добавлением настойки женьщеня и экстракта элеутерококка

\begin{tabular}{|c|c|c|}
\hline Показатель & Значение показателя напитка & $\begin{array}{l}\text { Значение показателя } \\
\text { по ГОСТ 28188-2014 }\end{array}$ \\
\hline $\begin{array}{l}\text { Внешний вид } u \\
\text { консистенцฺия }\end{array}$ & $\begin{array}{l}\text { непрозрачная жидкость, без осадка и } \\
\text { посторонних частиц }\end{array}$ & $\begin{array}{l}\text { непрозрачная жидкость; допус- } \\
\text { кается наличие осадка и взве- } \\
\text { сей, обусловленных особенно- } \\
\text { стями используемого сырья, } \\
\text { без включений, не свойствен- } \\
\text { ных продукту }\end{array}$ \\
\hline Цвет & светло-бежевый & \multirow{3}{*}{$\begin{array}{l}\text { свойственный добавленным } \\
\text { компонентам согласно рецеп- } \\
\text { туре }\end{array}$} \\
\hline 3 anax & с тоном элеутерококка & \\
\hline Bкyc & $\begin{array}{l}\text { сладкий, свойственный добавлен- } \\
\text { ным компонентам }\end{array}$ & \\
\hline
\end{tabular}

Источник: составлено авторами

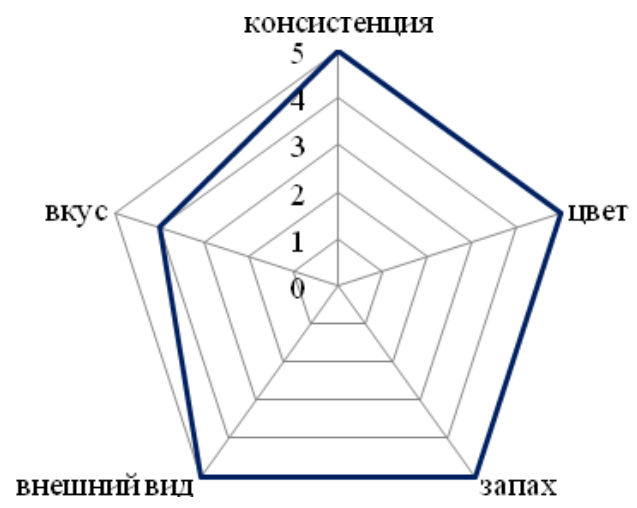

Puc. 4. Органолептическая оценка приготовленного напитка на основе пектина с добавлением женьшеня и элеутерококка

Источник: составлено авторами

Из табл. 2 и рис. 4 видно, что напиток на основе пектина из филлоспадикса, обогащенный экстрактом элеутерококка и настойкой женьшеня, по органолептическим показателям соответствовал ГОСТ 28188-2014.

Профилограмма вкусового комплекса напитка на основе пектина из филлоспадикса с добавлением женьшеня и элеутерококка представлена на рис. 5. 


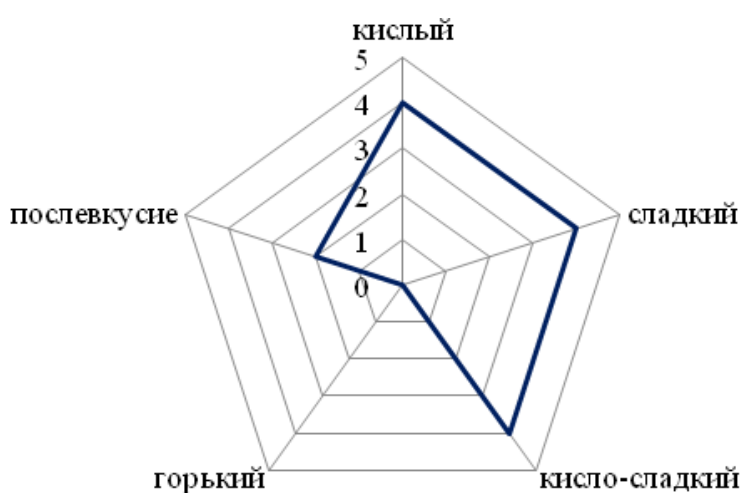

Puc. 5. Профилограмма вкусового комплекса напитка на основе пектина с добавлением женьшеня и элеутерококка

Источник: составлено авторами

Вкус образца напитка не имеет отрицательных для потребителя свойств. Можно отметить выраженный кисло-сладкий вкус, обусловленный добавлением витамина $\mathrm{C}$, лимонной кислоты и стевиозида.

На рис. 6 отражена профилограмма внешнего вида напитка.

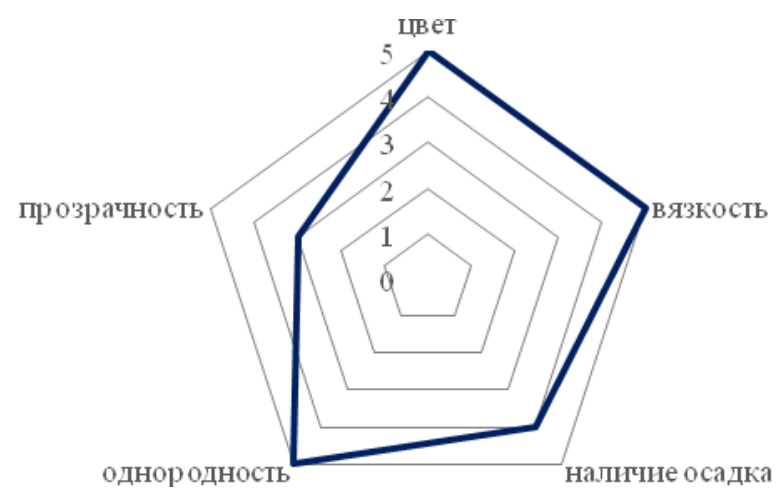

Puc. 6. Профилограмма внешнего вида напитка на основе пектина с добавлением женьшеня и элеутерококка

Источник: составлено авторами

Внешний вид напитка также не имеет проявления отрицательных для потребителя свойств. Консистенция напитка вязкая, полупрозрачная, однородная, с небольшим осадком. Светло-бежевый цвет соответствует добавленным компонентам.

При исследовании физико-химических показателей определяли массовую долю сухих веществ, влажность и минеральные вещества сухого концен- 
трата напитка, а также титруемую кислотность в готовом напитке в соответствие с действующей НД.

Массовая доля сухих веществ сухого концентрата напитка составила $93,8 \pm 0,1$. Массовая доля минеральных веществ в сухом концентрате напитка составила 4,530 $\pm 0,001$ г и находится в пределах нормы.

Влажность контрольных образцов сухого концентрата напитка составила $6,2 \pm 0,1 \%$, что соответствует допустимым значениям.

Титруемая кислотность напитка составила $2,4 \pm 0,03 \mathrm{~cm}^{3}$, что соответствуют нормам ГОСТ 6687.4-86 (не корректно ссылаться здесь на этот метод. Это сам метод определения кислотности в напитках, а не требования по кислотности к напиткам) и ТР ТС 021/2011 (при допустимых уровнях значений $\left.1,0-15,0 \mathrm{~cm}^{3}\right)$. Кислотность напитка обуславливается самим пектином, лимонной и аскорбиновой кислотой, а также органическими кислотами, поступающими с экстрактом элеутерококка и настойкой женьшеня.

\section{Заключение}

Разработана технология и рецептура композиции сухого концентрата напитка на основе модифицированного пектина из филлоспадикса и природных адаптогенов Дальневосточного региона - женьшеня и элеутерококка. Обосновано соотношение функциональных ингредиентов в сухом концентрате напитка, определены дозы всех ингредиентов с учетом норм их потребления и данных физико-химических исследований. Полученный сухой концентрат напитка является функциональным по содержанию пектина, гинсенозидов, элеутерозидов и аскорбиновой кислоты, содержание каждого из которых в однократной дозировке напитка $(10,0$ г) составляет $100 \%$ от адекватного суточного уровня потребления.

\section{Список источников / References}

1. Валышев А.В. Антимикробная активность пектинов и их производных [Valyshev A.V. Antimikrobnaya aktivnost' pektinov i ikh proizvodnykh [Antimicrobial activity of pectins and their derivatives]. Available at: http://elmag.uran.ru:9673/magazine/Numbers/2013-3/Articles/ValyshevAV(20133).pdf.

2. Потороко И.Ю. и др. Антиоксидантные свойства функциональных пищевых ингредиентов, используемых при производстве хлебобулочных и молочных продуктов, их влияние на качество и сохраняемость продукции. Вестник ВГУИТ, 2017, т. 79, №4, cc. 143-151. [Potoroko I.Yu. i dr. Antioksidantnye svoistva funktsional'nykh pishchevykh ingredientov, ispol'zuemykh pri proizvodstve khlebobulochnykh i molochnykh produktov, ikh vliyanie na kachestvo i sokhranyaemost' produktsii [Antioxidant properties of functional food ingredients used in the production of bakery and dairy products, their impact on the quality and persistence of products]. Vestnik VGUIT = Bulletin of VSUET, 2017, vol. 79, no. 4, pp. 143-151.]

3. Хобракова В.Б. Перспективы использования средств растительного происхождения для коррекции иммунодефицитов. Бюллетень ВСНЦ СО РАМН, 2010, №3 (73), cc. 278-280. [Khobrakova V.B. Perspektivy ispol'zovaniya sredstv rastitel'nogo proiskhozhdeniya dlya korrektsii immunodefitsitov [The prospects of plant origin 
agents use for the immunodeficiencies correction] Vestnik of VSNC SO RAMN = Bulletin of SSC of RAMS, 2010, no. 3 (73), pp. 278-280.]

4. Шашель В.А. и др. Реабилитация в условиях бальнеолечебницы детей с эрозивно-язвенными заболеваниями желудка и двенадцатиперстной кишки, проживающих на территориях с неблагоприятными экологическими условиями. Медицинский вестник Северного Кавказа, 2011, №2, сс. 16-19. [Shashel' V.A. i dr. Reabilitatsiya v usloviyakh bal'neolechebnitsy detei s erozivno-yazvennymi zabolevaniyami zheludka i dvenadtsatiperstnoi kishki, prozhivayushchikh na territoriyakh s neblagopriyatnymi ekologicheskimi usloviyami [Rehabilitation in the conditions of balneological hospitals of children with erosive and ulcerative diseases of the stomach and duodenum, living in areas with adverse environmental conditions] Medical Bulletin of the North Caucasus, 2011, no. 2, pp. 16-19.]

5. Khozhaenko E.V. et al. Metal binding activity of pectin isolated from seagrass Zostera marina and its derivatives. Russian Journal of Marine Biology, 2015, vol. 41, no. 6, pp. 485-489. DOI 10.1134/S1063074015060073.

6. Коленченко Е.А., Хотимченко М.Ю., Хожаенко Е.В., Хотимченко Ю.С. Сорбция стронция пектинами, выделенными из морских трав Zostera marina и Phyllospadix iwatensis. Биология моря, 2012, т. 38, №4, cc. 325-329. [Kolenchenko E.A., Khotimchenko M.Yu., Khozhaenko E.V., Khotimchenko Yu.S. Sorbtsiya strontsiya pektinami, vydelennymi iz morskikh trav Zostera marina i Phyllospadix iwatensis [Strontium sorption by pectins isolated from marine seagrasses Zostera marina and Phyllospadix iwatensis]. Russian Journal of Marine Biology, 2012, vol. 38, pp.325-329.]

7. Khotimchenko Yu., Khozhaenko E., Kovalev V., Khotimchenko M. Cerium binding activity of pectins isolated from the seagrasses Zostera marina and Phyllospadix iwatensis. Marine drugs, 2012, vol. 10, no. 4, pp. 834-848. DOI: $10.3390 / \mathrm{md} 10040834$

8. Khozhaenko E., Kovalev V., Podkorytova E., Khotimchenko M. Removal of the metal ions from aqueous solutions by nanoscaled low molecular pectin isolated from seagrass Phyllospadix iwatensis. Science of the total environment, 2016, vol. 565, pp. 913-921. DOI: 10.1016/j.scitotenv. 2016.01.108

9. Подкорытов А.Г., Кадникова И.А., Подкорытова Е.А. Разработка технологии сухого концентрата напитка на основе пектина из морской травы Phyllospadix iwatensis с добавлением экстракта элеутерококка Eleutherococcus senticosus. Известия ДВФУ. Экономика и управление, 2018, №2, сc. 156-168. [Podkorytov A.G., Kadnikova I.A., Podkorytova E.A. Razrabotka tekhnologii sukhogo kontsentrata napitka na osnove pektina iz morskoi travy Phyllospadix iwatensis s dobavleniem ekstrakta eleuterokokka Eleutherococcus senticosus] The technology development of a dry concentrate pectin-based beverage from seagrass Phyllospadix iwatensis with the addition of Eleutherococcus senticosus extract]. Izvestiya DVFU = News of FEFU. Economics and Management, 2018, no. 2, pp. 156-168.]

10. Котик О.А. Перспективы использования растительных экстрактов с высокой антиоксидантной активностью в квасах брожения. Известия вузов. Пищевая технология, 2012, №4, сc. 26-29. [Kotik O.A. Perspektivy ispol'zovaniya rastitel'nykh ekstraktov s vysokoi antioksidantnoi aktivnost'yu v kvasakh brozheniya [Prospects of plant extracts with high antioxidant activity use in the kvass fermentation.] Izvestiya vuzov = News of universities. Food technology, 2012, no. 4, pp. 26-29.] 
11. Гумеров Т.Ю., Решетник О.А. Роль природных адаптогенов при оценке качества напитков спортивного и функционального назначения. Вестник Казанского технологического университета, 2013, т. 16, №18, cс. 219-223. [Gumerov T.Yu., Reshetnik O.A. Rol' prirodnykh adaptogenov pri otsenke kachestva napitkov sportivnogo i funktsional'nogo naznacheniya [The natural adaptogens role in assessing the quality of sports and functional beverages] Vestnik $K T U=$ Bulletin of $K T U, 2013$, vol. 16, № 18, pp. 219-223.]

12. Куркин В.А., Акушская А.С. Разработка методов контроля качества женьшеня настойки. Химия растительного сырья, 2013, №2. сс. 177-182. [Kurkin V.A., Akushskaya A.S. Razrabotka metodov kontrolya kachestva zhen'shenya nastoiki [Quality control methods development for ginseng tinctures] Khimiya rastitel'nogo syr'ya, 2013, № 2. pp. 177-182.]

13. Подкорытов А.Г., Кадникова И.А., Подкорытова Е.А., Ковалев В.В. Разработка технологии сухого концентрата напитка на основе модифицированного пектина с добавлением дикоросов Дальнего Востока. Известия ДВФУ. Экономика $и$ управление, 2019, №3, сc. 165-177. [Podkorytov A.G., Kadnikova I.A., Podkorytova E.A., Kovalev V.V. Razrabotka tekhnologii sukhogo kontsentrata napitka na osnove modifitsirovannogo pektina s dobavleniem dikorosov Dal'nego Vostoka [Development of technology of a dry concentrate beverage based on modified pectin with the addition of Far East wild plants]. Izvestiya DVFU = The Bulletin of FEFU. Economics and Management, 2018, no. 2, pp. 113-126.]

14. Единые санитарно-эпидемиологические и гигиенические требования к продукции (товарам), подлежащей санитарно-эпидемиологическому надзору (контролю) (утв. Решением Комиссии таможенного союза от 28 мая 2010 года N 299) (с изменениями на 10 мая 2018 года) (редакция, действующая с 1 июня 2019 года). [Edinye sanitarno-epidemiologicheskie i gigienicheskie trebovaniya $\mathrm{k}$ produktsii (tovaram), podlezhashchei sanitarno-epidemiologicheskomu nadzoru (kontrolyu) (utv. Resheniem Komissii tamozhennogo soyuza ot 28 maya 2010 goda N 299) (s izmeneniyami na 10 maya 2018 goda) (redaktsiya, deistvuyushchaya s 1 iyunya 2019 goda) [Unified sanitary-epidemiological and hygienic requirements for products (goods) subject to sanitary-epidemiological supervision (approved by the Decision of the Commission of the Customs Union No. 299 of May 28, 2010) (Amended on May 10, 2018) (revised from June 1, 2019)]. Available at: http://docs.cntd.ru/document/902249109\# (accessed 04.07.2018).

\section{Сведения об авторах / About authors}

Подкорытов Андрей Геннадьевич, аспирант Департамента пищевых наук и технологий, Школа биомедицины, Дальневосточный федеральный университет. 690922 Россия, г. Владивосток, о-в Русский, кампус ДВФУ, корпус M. ORCID ID: 0000-0003-4831-5514.

E-mail: podkorytov.ag@dvfu.ru

Andrey G. Podkorytov, Postgraduate Student, Department of Food Science and Technology, School of Biomedicine, Far Eastern Federal University. Building M, FEFU campus, Russky Island, Vladivostok, Russia 690922. ORCID ID: 0000-0003-4831-5514. E-mail: podkorytov.ag@dvfu.ru 
Кадникова Ирина Арнольдовна, доктор технических наук, профессор Департамента пищевых наук и технологий, Школа биомедицины, Дальневосточный федеральный университет. 690922 Россия, г. Владивосток, о-в Русский, кампус ДВФУ, корпус М.

E-mail: kadnikova.ia@dvfu.ru

Irina A. Kadnikova, Doctor of Technical Sciences, Professor, Department of Food Science and Technology, School of Biomedicine, Far Eastern Federal University. Building M, FEFU campus, Russky Island, Vladivostok, Russia 690922. E-mail: kadnikova.ia@dvfu.ru

Подкорытова Елена Алексеевна, кандидат биологических наук, научный сотрудник Лаборатории фармакологии ФГБУН «Национальный научный центр морской биологии имени А.В. Жирмунского» ДВО РАН. 690041, Россия, г. Владивосток, ул. Пальчевского, д. 17.

E-mail: eapodkorytova@mail.ru

Elena G. Podkorytova, Candidate of Biological Sciences, Researcher, Laboratory of Pharmacology, Federal State Budgetary Institution "National Scientific Center for Marine Biology named after A.V. Zhirmunsky" FEB RAS. 17, Palchevskogo Str., Vladivostok, Russia 690041.

E-mail: eapodkorytova@mail.ru

Ковалев Валерий Владимирович, кандидат биологических наук, старший научный сотрудник Лаборатории фармакологии ФГБУН «Национальный научный центр морской биологии имени А.В. Жирмунского» ДВО РАН. 690041, Россия, г. Владивосток, ул. Пальчевского, д. 17. E-mail: kovalev.ibm@gmail.com

Valery V. Kovalev, Candidate of Biological Sciences, Senior Researcher, Laboratory of Pharmacology, Federal State Budgetary Institution "National Scientific Center for Marine Biology named after A.V. Zhirmunsky" FEB RAS. 17, Palchevskogo Str., Vladivostok, Russia 690041.

E-mail:kovalev.ibm@gmail.com

(C) Подкорытов А.Г., Кадникова И. А., Подкорытова Е.А., Ковалев В.В. (C) Podkorytov A.G., Kadnikova I.A., Podkorytova E.A., Kovalev V.V. Адрес сайта в сети интернет: http://jem.dvfu.ru 